\title{
COVID-19, Moral Injury and the Bhagvad Gita
}

\author{
Bindu Menon $^{1}$ (D) Sunil K. Narayan ${ }^{2} \cdot$ Sushruth Bhade ${ }^{3}$
}

Accepted: 12 February 2021 / Published online: 26 February 2021

(c) The Author(s), under exclusive licence to Springer Science+Business Media, LLC part of Springer Nature 2021

\begin{abstract}
During life challenging times like the present COVID-19 pandemic, the health care worker $(\mathrm{HCW})$ is faced with a number of questions of an existential nature. There is a sense of guilt, anguish, helplessness, uncertainty and powerlessness when one is fighting something on such a powerful scale with limited resources and no definite end in sight. There are circumstances when these feelings can overwhelm a person leading to demoralization and potentially a moral injury. Spiritual practices and advice may help to deal with moral paradoxes and ethical dilemmas when other secular supports are undermined or inaccessible. The Holy Indian Epic, the Bhagvad Gita has described the moral distress of the warrior Arjuna, during the battle of Kurukshetra and the advice given to him by the Lord Krishna the gist of which can be encapsulated in the form of the four Ds- Detachment, Duty, Doer-ship and Dhyana or meditation. In this article, the authors explore how these concepts may be useful aids to the HCW faced with moral and psychological distress.
\end{abstract}

Keywords Hindu philosophy · The Bhagvad Gita · COVID-19 and health care

\section{Introduction}

Moral injury is a complex term which may be difficult to define (Hodgson \& Carey, 2017) but can be explained as the consequence of being forced to do, witness, fail to prevent or comply with something that goes against an individual's deeply ingrained code of social ethics and or personal morality. Moral injury is not a mental illness but may be a contributory factor for it, resulting in symptoms of anxiety, depression or even posttraumatic stress disorder. It was first described by Jonathan Shay,

Bindu Menon

bindumen@gmail.com

1 Department of Psychiatry, Sri Venketeshwaraa Medical College, Ariyur, Pondicherry 605102, India

2 Department of Neurology, Jawaharlal Institute of Postgraduate Medical Education and Research( JIPMER), Dhanvanthari Nagar, Pondicherry 605006, India

3 Midam Charitable Trust, Pondicherry, India 
in his book on Vietnam War veterans 'Achilles in Vietnam-combat trauma and the undoing of character' (Shay, 1994). Though moral injury had been initially identified in war veterans, similar situations and ethical dilemmas can also occur in health care settings, hence the term has been borrowed to describe the distress and conflicts experienced by various caring professions working in adverse situations (Williamson, 2018). Moral injury (MI) may lead to feelings of guilt, shame, remorse or even anger. It differs from burnout which also has similar psychological and physical symptoms. However, MI may lead to burnout. ${ }^{1}$

In any acute health care crisis, such as during the current COVID-19 pandemic, moral injury can result given a number of scenarios within clinical settings. There are numerous bioethical choices to be made. These include allocation of scarce resources like ventilators and protective equipment, obeying the institutional and hierarchic rules especially when one is at the bottom of the pecking order, personal safety and the risk to one's family as a result of performing one's duty - to name a few. A moral paradox to the Health Care Worker (HCW) is when the principles of altruism, beneficence and self-sacrifice in course of performing one's duty come in direct conflict with one's personal well-being (Flew and Priest, 2002). More so in the COVID scenario, where the front line HCW may pose a risk of being a carrier of the virus resulting in infection to their own loved ones. Often the decisions one makes, or are forced to make may evoke feelings of guilt, culpability, powerlessness and distress. There may be a perceived loss of professional integrity and identity. The feeling that one has not done the right thing or failed to prevent something wrong, gives rise to the feeling of being a 'bad person' (Greenberg et al., 2020; Williams et al., 2020).

Moral injury in this situation can lead to impaired mental and physical functioning of the individual, including a number of psychosomatic symptoms like insomnia, fatigue, muscular tension, myalgia, headaches and gastrointestinal upset (Dubey et al., 2020). Psychological symptoms of depression, anxiety, suicidal ideas and demoralization are to be expected in this situation. Conventional protective factors like social support, company of friends and means of entertainment have also been restricted; worsening the situation. COVID-19 has actually unleashed a pandemic of global mental ill health.

The current COVID-19 pandemic is at a time when the world is facing an unprecedented war-like situation. The HCWs dealing with the COVID 19 pandemic are especially at a high risk of stress, anxiety, depression and other mental health problems. There is an urgent need to implement interventions that promote mental health in these professionals. Unfortunately, access to formal psychotherapy is often limited, impractical due to time constraints or fraught with stigma. Another issue is the paucity of mental health professionals.

In such troubled times, one looks everywhere for answers, and may even turn to spiritual guidance through the teachings of prophets, saints, spiritual leaders and to the wisdom of the ancient texts to find answers to tormenting existential questions.

\footnotetext{
1 Moral Injury: For a more comprehensive definition refer to Carey and Hodgson (2018). Frontiers in Psychiatry https://www.frontiersin.org/articles/10.3389/fpsyt.2018.00619/full.
} 
Shay (1994) had likened the psychological trauma of Vietnam war veterans to the struggle and distress of Achilles and his soldiers during the long war against Troy. In the Indian epic, The Mahabharata, we have a robust example of moral injury; in the dilemma of Arjuna, the ace warrior of the Pandavas and the prescribed remedy given by none other than the Lord, Sri Krishna in the form of the Bhagavad Gita.

In this article, the authors would like to explore the verses from the Bhagavad Gita to explore the relevance of the advice contained therein to the present turmoil and mental stress experienced by the people at large and more specifically the HCW.

\section{Background: The Bhagavad Gita}

The Bhagavad Gita (Gitopanishad) literally means-Song of the Divine. It is revered as holy by the Hindus. It originally appears as an episode in the Mahabharata, the epic story of the battle between cousins, the children of Pandu (Pandavas) and Dhritharashtra (Kauravas). The Pandavas, who had to face persecution and injustice from their own kin, had Lord Krishna on their side as friend, mentor and adviser. He motivates the third of the five Pandavas, Arjuna, to fight, offering himself as his charioteer and guide. Lord Krishna is revered as an avatara or incarnation of Lord Vishnu, the sustainer of the universe in the Hindu holy trinity of Bhramha (the creator), Vishnu (the sustainer) and Shiva (the destroyer).

The ancient wisdom of the Gita imparted by Krishna, which is essentially a friendly dialog between a wise teacher and a disillusioned student, has of late kindled interest as a model for psychotherapy (Reddy, 2012; Pandurangi et al., 2014).

The teachings comprise 700 verses and 18 chapters (25-42) of the Bhishmaparva of Mahabharata, (Sukthanker, 1940; Bhade, 2014). We see, in these verses, how a demoralized Arjuna expresses his ethical dilemma about killing his own cousins and teachers in the battlefield of Kuruskhetra. He expresses his unwillingness to perform his duty as a warrior, of fighting against 'Adharma' or injustice. After Lord Krishna's counsel, he comes a full circle and declares with confidence that his delusion has been destroyed and he is now ready to fight to uphold his Dharma-his duty.

The relevant verses from the Gita (an English translation of the original by one of the co-authors) and their significance in current times of COVID-19 are highlighted as follows. 


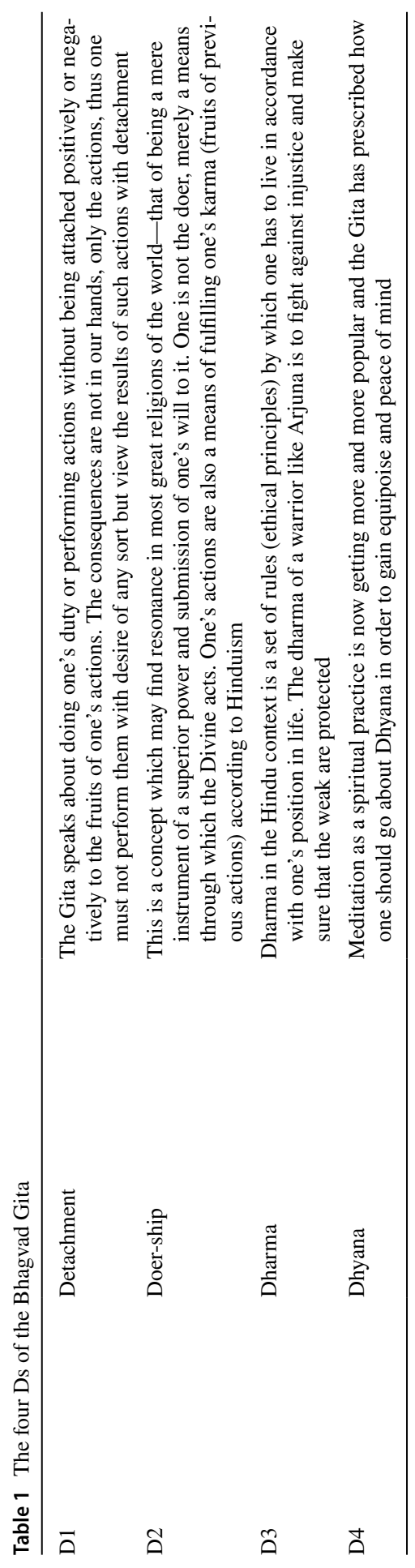




\section{The Four Concepts of the Gita: The Four Ds}

Four concepts from the Gita namely-(1) 'Detachment,' (2) 'Doer and the concept of Self,' (3) 'Dharma or Duty' and (4) 'Dhyana or Meditation'; the four Ds hold specific relevance and therapeutic potential in offering psychological support to HCWs (also see Table 1).

For the original verses from the Gita, please see "Appendix 1."

\section{Detachment}

Many HCWs have reported feeling let down as a result of working with insufficient resources, personal protective equipment and staffing (Greenberg et al., 2020; Williams et al., 2020).

In the Gita, we find Arjuna experiencing a similar feeling of sorrow at having been placed in apposition where he has to inflict injury to his own kin. Krishna's introduction of the principle of Detachment can be of great relevance to HCWs. He tells Arjuna to recognize that all emotions are just fleeting sensations of mind and ask him to engage in Karma Yoga stating "Yoga Karmasu Kaushalam" meaning detachment, yet excellence in works is Yoga. The important thing to note here is that detachment does not mean running away or shrugging away responsibility. It just means being detached from the consequences of the action that is performed to the best of one's ability, whatever the circumstances one is placed in.

"Vested you are with the authority to perform**

But not seek your action's fruits in any form

When by the fruits of actions you aren't motivated

From discharging your duties, you never get deviated 2.47

Perform your every action in this Yogic way

all attachments Arjuna, you must throw away

From accomplishments and loss find your release

Then you shall attain the Yogic poise and peace". 2.48 (Also, see "Appendix 1 ')

\section{Doer-Ship: The Concept of the Self}

Moral responsibility for the choices one is forced to make can lead to moral injury especially when one feels helpless that the decision-making is not one's own but conformity to protocol, authority or political correctness. Where there are such moral paradoxes, the advice of Krishna becomes relevant and is very valuable. Krishna introduces the concept of the individual 'Self' as being part of the universal Self or cosmos and the interconnectedness of oneself to all things both sentient and 
insentient (living and non-living). This helps to reduce one's sense of alienation and paradoxically, also one's 'ego.' We are all important but not indispensable; we are all interconnected in a cosmic web and not isolated. We are not the doers, but instruments of a higher power. This frees us from doer-ship.

"The knower of the true principles of existence

Knows that he is not the cause of his subsistence.5.8

$\mathrm{He}$ is not the doer of works, but his work is done." 4.20 (Also, see "Appendix 1")

\section{Dharma or Duty}

For the COVID 'warriors' including the HCW, doing one's duty is not a new concept. Fighting sickness and disease, in adverse circumstances, trying to save lives is considered to be the mission of healing professionals. This duty often comes in direct conflict with self-preservation and the risk of infection to family and loved ones. Fast tracking of new medical students and residents to overcome man power shortages has created situations where the competency and mental health of newly appointed employees are to be monitored with utmost care (Greenberg et al., 2020).

In these individuals, exposing colleagues or patients to danger due to either inexperience, indecisiveness or while working beyond the expected or normal competency is an inevitable result leading on to further distress and guilt.

The concept of Dharma or Duty of the Gita as explained by Krishna to Arjuna can offer solace to the 'corona warriors' who have experienced moral distress while performing their duty. Krishna tells Arjuna that for a warrior the most appropriate thing was to defend the integrity of his duty. Krishna also tells Arjuna to not have the guilt of defective action and never abandon one's duties by stating that making mistakes is a natural phenomenon.

"Your Dharma-moral duty you must consider

And from it, you most definitely mustn't falter.2.31

Even if defectively done, as all actions are cloaked with defect

Just as the fire is masked by its own smoke's effect." 18.48 (Also, see "Appendix 1")

Dharma does not mean just duty; in this context, it has a wider scope and meaning. It means upholding ethical principles to the extent one can, while giving one's best efforts in fulfilling one's mission; without the sense of doer-ship and with detachment from the results of the action; which may result in saving someone's life or regrettably sometimes letting death happen.

It is only in such performance of duty that one can attain a sense of accomplishment and happiness. This thought finds an echo in Viktor Frankl's book "Mans Search for Meaning" (Frank1, 1962). 
Frankl explains that without a mission, one loses the will to live and life becomes meaningless. A mission, he says is not some grand purpose, it is just something that only you as an individual can do, based on the peculiar circumstances you are placed in. It need not be perfect, it need not be grand and it may be defective. To have tried to do something to the best of your abilities, even in adverse circumstances, is what makes the difference. That is Dharma according to the Gita.

\section{Dhyana or Meditation}

Meditation, as a spiritual practice, has shown to significantly reduce stress and improve the general mental health, mindful attention and self-efficacy in patients with acute respiratory illnesses (Barrett et al., 2018).

As a cognitive corollary of the physical wellness mediation provides, a realistic, bold and detached outlook focused on one's duties to oneself and others without fear, guilt or panic could foster a healthy protective immune response in human body. This may have a potential to promote a positively modulated psychoneuroimmnological response of the human biological system (Bonneau et al., 2007).

Some verses recommending meditative practices from the Gita are highlighted as follows (Also, see "Appendix 1").

"Shunning all external touches they concentrate,

focusing at the center between eyebrows, they meditate

controlling the life force entering and leaving the nostril

Their inhalation and exhalation, they equalize by their will 5.27

Step by step one must gradually turn inwards

And think of nothing else that is outwards

With the intelligence focused in concentration

One must engage in the Self's meditation." 6.2

\section{Conclusion}

The message of the Gita is universal. The religious and the secular, the Hindu and the non-Hindu alike can derive solutions from it for addressing moral injury and ethical dilemmas. Almost all religions of the world endorse doing one's duty, rooted in righteousness and submission of all one's actions and their results or consequences; even be it death to the highest power. The secular can draw inspiration from the concept of the universal interconnectedness of all things and the wisdom of doing what one can do to the best of one's ability while accepting what one cannot change. 


\section{Appendix 1: Original Verses from the Gita and Their Translation by Swami Prabhupada, 'The Bhagavad Gita as it is' (1986), Bhaktivedanta Book Trust}

The first column refers to the chapter in the Gita from where the verses are taken (Prabhupada 1986).

The verses are given in the order quoted within the text of this article.

\begin{tabular}{lll}
\hline Verse no. & Original verse & Translation into English \\
\hline
\end{tabular}

$2.47 \quad$ Karmanye vadhikarasthe maphaleshukadachan

Ma karmaphala hetur,ma te sangostv akarmani

$2.48 \quad$ Yogastha kuru karmani,sangam tyaktva dhanajaya,

Siddya-asiddhyo samabhutwa,samatwam yoga uchyate

$5.9 \quad$ Naiva kinchit karomiti yukto manyeta tattva-vit

Pasyan,sravan,sparshan,jhjigran,asnan gachhan svapan,svasan

pralapan,visrajan, grahnan,unmisan,nimi san api

Indriyanindriyanarthesu varthantha ithi dharayan

4.20 Tyaktva karmaphala sangam nitya trypto nirashraya

Karmany abhipravrttopi naiva kincit karoti sah

2.31 Sva dharmam api sa avekshya na vikampitum arhasi

Dharmayad dhi yudhhac chreyo'nyat ksathriyasya na vidyate

18.48 Shajam karma kaunteya,sa dosham api na tyajet

Sarvarambhahi doshena dhumenagnir ivavratah

5.27 Sparshan krittva bahir bahyams' caksus caivantare bhruvoh

Pranapanu sam krittva nasabhyantara carinau

Yatendriya-mano-buddhir munir moksha parayana

Vigateccha bhaya -krodho ya sada mukta eva sah

6.25 Sanaih sanair uparamed buddhya dhritirgrihatya

Atma samstham manah krtva na kincit api chintayet

You have a right to perform your prescribed duty but you are not entitled to the fruits of your action. Never consider yourself as the cause of the result of your activities and never to be attached to not doing your duty

Perform your duty equipoise, O Dhananjaya (Arjuna) abandoning all attachment to success or failure. Such equanimity is called yoga

A person in divine consciousness, although engaged in hearing, touching, smelling, eating, moving about, sleeping and breathing always knows within himself that he actually does nothing at all. He always knows that only the material senses are engaged and that he is aloof from it all

Abandoning all attachment to results of his activities, ever satisfied and independent, he performs no action though apparently engaged in all kinds of undertakings

Considering your specific duty as a kshatriya (warrior) you should know that there is no better engagement for you than fighting for righteousness, so there is no need for hesitation

Every endeavor is covered by some fault, just a fire is covered by smoke. Therefore, one should not give up work O son of Kunti, even if such work is full of fault

Shutting out all external objects, keeping eyes and vision concentrated between two eyebrows, suspending the inward and outward breaths within the nostrils and thus controlling mind, senses and intelligence, the transcendentalist aiming at liberation becomes free from desire, fear and anger, who is always in this state is certainly liberated

Gradually step by step one should become situated in trance by means of intelligence sustained by full conviction and thus the mind should be fixed on the self alone and should think of nothing else 
Acknowledgements The translation into English from the original Sanskrit verses is by the 3rd coauthor. He has used the version of the Gita as expounded by Sukthankar V, (Reference No. 11, 12). The original Sanskrit verses are quoted in "Appendix 1" attached alongside. The translation by Shri Swami Prabhupada, founder of International society of Krsna consciousness (ISKON), is also given (Ref 14).

\section{Compliance with Ethical Standards}

Conflict of interest The authors have no conflict of interest to declare.

\section{References}

Badhe, S. (2015). Bhagavad Gita: Rhythm of Krishna. Sri Aurobindo's Action Publications.

Barrett, B., Hayney, M. S., Muller, D., Rakel, D., Brown, R., Zgierska, A. E., Barlow, S., Hayer, S., Barnet, J. H., Torres, E. R., \& Coe, C. L. (2018). Meditation or exercise for preventing acute respiratory infection (MEPARI-2): A randomized controlled trial. PLOS ONE, 13(6), e0197778. https://doi. org/10.1371/journal.pone.0197778

Bonneau, R. H., Padgett, D. A., \& Sheridan, J. F. (2007). Twenty years of psychoneuroimmunology and viral infections in Brain, Behavior, and Immunity. Brain, Behavior, and Immunity, 21(3), 273-280. https://doi.org/10.1016/j.bbi.2006.10.004

Carey, L. B., \& Hodgson, T. J. (2018). Chaplaincy, spiritual care and moral injury: Considerations regarding screening and treatment. Frontiers in Psychiatry, 9(619), 1-10. https://doi.org/10.3389/ fpsyt.2018.00619/full

Dubey, S., Biswas, P., Ghosh, R., Chatterjee, S., Dubey, M. J., Chatterjee, S., Lahiri, D., \& Lavie, C. J. (2020). Psychosocial impact of COVID-19. Diabetes \& Metabolic Syndrome, 14(5), 779-788. https ://doi.org/10.1016/j.dsx.2020.05.035

Flew, A., \& Priest, S. (Eds.). (2002). A dictionary of philosophy. Pan books.

Frankl, V. E. (1962). Man's search for meaning: An introduction to logotherapy. Beacon Press.

Greenberg, N., Docherty, M., Gnanapragasam, S., \& Wessely, S. (2020). Managing mental health challenges faced by healthcare workers during covid-19 pandemic. British Medical Journal (Clinical Research Ed.), 368, m1211. https://doi.org/10.1136/bmj.m1211

Hodgson, T. J., \& Carey, L. B. (2017). Moral injury and definitional clarity: Betrayal, spirituality and the role of chaplains. Journal of Religion and Health, 56(4), 1212-1228. https://doi.org/10.1007/ s10943-017-0407-z

Pandurangi, A. K., Shenoy, S., \& Keshavan, M. S. (2014). Psychotherapy in the Bhagavad Gita, the Hindu scriptural text. The American Journal of Psychiatry, 171(8), 827-828. https://doi.org/10.1176/appi. ajp.2013.13081092

Prabhupada, S. (1986). The Bhagavad Gita as it is (2nd ed.). Bhaktivedanta Book Trust.

Reddy, M. S. (2012). Psychotherapy: Insights from Bhagavad Gita. Indian Journal of Psychological Medicine, 34(1), 100-104. https://doi.org/10.1177/0975156420120102

Shay, J. (1994). Achilles in Vietnam: Combat trauma and the undoing of character. USA: Scribner.

Sukthankar, V. S. (1940). The Mahābhārata: For the first time critically edited. Bhandarkar Oriental Research Institute.

Williams, R. D, Brundage, J. A., \& Williams, E. B. (2020). Moral Injury in Times of COVID-19. Journal of Health Service Psychology, 46, 65-69. Advance online publication. https://doi.org/10.1007/s4284 3-020-00011-4

Williamson, S. S., \& Greenberg, N. (2018). Occupational moral injury and mental health: Systematic review and meta-analysis. The British Journal of Psychiatry, 212(6), 339-346. https://doi. org/10.1192/bjp.2018.55

Publisher's Note Springer Nature remains neutral with regard to jurisdictional claims in published maps and institutional affiliations. 